\title{
The Views of Elite Bodybuilding Athletes Concerning Doping Training, Their Level of Knowledge about Doping, and Values Education in Sport
}

\author{
Özer Yıldız ${ }^{1, *}$ \\ ${ }^{1}$ Faculty of Education, Necmettin Erbakan University, Konya 42090, Turkey \\ *Correspondence: Faculty of Education, Necmettin Erbakan University, Konya 42090, Turkey. E-mail: \\ oyildiz74@gmail.com
}

Received: December 14, 2018

Accepted: January 3, 2019 Online Published: January 21, 2019

doi:10.5430/wje.v9n1p56

URL: https://doi.org/10.5430/wje.v9n1p56

\begin{abstract}
The objective of this research study is to reveal the levels of knowledge of the elite bodybuilding athletes and their views about doping training; additionally, to evaluate the views of the participants from the standpoint of sport values education. The research was conducted as a phenomenology model, which is one of the qualitative research methods, and interview method was used. The research group was comprised of 13 national athletes ( 3 women and 10 men) from Turkey in bodybuilding branch. The 'Personal Information Form' and 'Interview Form', which were prepared by the researcher, were used. The data were analyzed via content analysis method, which is one of the qualitative research methods. Consequently, it was concluded that the bodybuilding athletes had low levels of knowledge concerning doping, national and international federations did not conduct information training about doping, it was important for the athletes to be successful in the contests, there was an increase in the use of doping, and that they were not competing on a level playing field.
\end{abstract}

Keywords: doping, elite athlete, bodybuilding, values education, sports

\section{Introduction}

Sport contributes to the ethical development of individuals to an extent. Sport represents only a dimension in teaching the ethical values to individuals and it facilitates the recognition of ethical values by individuals. In general, ethical and moral behaviors are learned in social environment. A sport activity, in itself, is neither moral nor ethical. Sport ethics is not a guarantee for the athletes to display ethical behaviors. Fair competition is only the responsibility of all of the shareholders in sport (Melzer, Elbe, \& Brand, 2010).

Despite numerous developments and research in recent years, use of doping in sport has increased in elite, amateur, and school sports in each passing day (Taware \& Bansode, 2016).

Today, doping substances are being used widely by the athletes. Madness of breaking a record and desire to satisfy the excited mobs cause the doping use. The motives behind the doping use for an athlete can be explained by winning, being a champion, shining amongst the rivals, and coming to an enviable position. Young athletes use the drugs without considering the harmful effects of the doping. Behaving with the belief 'Nothing happens to me', the athletes continue to purchase drugs with whatever is earned in the short term, and even some of them become addicted. Since the side effects are important as well as their effects, overdose and long term use of drugs as a doping creates very serious health problems that might end up with death (http://www.karate.gov.tr).

In order to protect the health of the athletes and provide the fair competition conditions, International Olympiad Committee (IOC), WADA, and International Sport Federations determined the performance increasing substances and methods that are considered as doping and prohibited them. However, the desire to win causes the athletes to abuse these methods and substances (Unal \& Ozer Unal, 2004).

While the main motive behind the struggle against doping was primarily the health of the athlete, by the time, a new view has been accepted that an athlete using doping is a 'cheating athlete', and since the sport has gained an economic importance, doping has turned into an 'economic crime'. In addition to financial worries, based on the corruption in the sportive values, the use of doping has turned into an ethical problem (Vatanoğlu \& Hot, 2011). 
Particularly in the recent years, the use of prohibited substances and methods has not been confined to sport, ultimately turning into a problem concerning the public health (Güner, 2016).

Therefore, it is important to examine the knowledge levels of the bodybuilding athletes concerning doping and to handle the issue through sport dimension of values education. The objective of this study is to determine the views of the elite bodybuilding athletes about the doping use and to determine their knowledge levels concerning doping; to reveal their views about the doping training organizations of national and international federations; additionally, to evaluate the doping in terms of values education in sports.

\section{Materials and Methods}

\subsection{The Research Model}

The research was conducted as a phenomenology model, which is one of the qualitative research models, and the interview method was used (Yıldırım \& Şimşek, 2006). This method is the best way to understand other individuals, to define the ideas of individuals about the problems (Punch, 2005), to examine the views of individuals and to reach the detailed information (Kuş, 2003), and to produce different solutions for the problems and to observe the characteristics (Işıkoğlu, 2005).

\subsection{Research Group}

The research group is comprised of 13 national athletes ( 3 women, 10 men) from Turkey. The 13 national bodybuilding athletes included in the interview were coded as "A1, A2, A3, .." in the data set as shown in the Table 1.

\subsection{Data Collection Tools}

There were 5 questions in the 'Personal Information Form', and there was 1 semi-structured and open ended question in the 'Interview Form', which were prepared by the researcher.

\subsection{Data Analysis}

The data were evaluated via the content analysis method of the qualitative research. Content analysis is comprised of four stages: coding the data, finding the themes, organizing and defining the data according to the themes and codes, and interpreting the findings (Yıldırım \& Şimşek, 2006).

Reliability analysis of the data was conducted via the Miles and Huberman (1994) formula (Tavşancıl \& Aslan, 2001):

$$
\text { Percentage of Agreement }=\frac{\text { Number of Agreed Themes (Codes) }}{\text { Number of Agreed and Dissenting Codes (Themes) }} x 100
$$

As the conclusion of the above formula for testing the reliability among the researchers conducting the coding, it is expected to be over $70 \%$. When the formula was applied, 9 out of 11 codes were approved, and an agreement was settled at $9 / 11 \times 100=81.8$ ratio about the reliability of the codings. The 3 codes that were kept outside the agreement were combined with other codes.

The answers that the bodybuilding athletes gave in the interviews were tabulated (Table 2) as frequency and percentage according to the repetition frequency.

\section{Results}

When the demographical features of the research group are examined in Table 1, it is determined that 10 of them are male, and 3 female, their ages are between 28 and 51, duration of experience in this branch are between 3 and 36, 8 athletes have bachelor's degrees and 5 of them own high school degrees concerning their educational status, the lowest number of international participation as a national athlete is 2 while the highest is 113 . 
Table 1. The Numerical Distribution of the Athletes Concerning Their Gender, Age, the Duration of Their Bodybuilding Experience, Their Educational Status, the Number of Participations in International Contests as a National Athlete, and the Date of the Interviews

\begin{tabular}{ccccccc}
\hline Codes & Gender & Age & $\begin{array}{c}\text { Duration of } \\
\text { Bodybuilding } \\
\text { Experience }\end{array}$ & $\begin{array}{c}\text { Educational } \\
\text { Status }\end{array}$ & $\begin{array}{c}\text { Number of } \\
\text { International Contest } \\
\text { Participation (National) }\end{array}$ & $\begin{array}{c}\text { Interview } \\
\text { Date }\end{array}$ \\
\hline A1 & Male & 46 & 20 & High School & 7 & 10.06 .2017 \\
A2 & Female & 33 & 3 & Bachelor & 2 & 10.06 .2017 \\
A3 & Male & 46 & 30 & Bachelor & 12 & 10.06 .2017 \\
A4 & Male & 51 & 36 & High School & 113 & 10.07 .2017 \\
A5 & Male & 29 & 10 & Bachelor & 2 & 10.07 .2017 \\
A6 & Male & 39 & 22 & Bachelor & 2 & 10.07 .2017 \\
A7 & Male & 35 & 18 & High School & 2 & 10.07 .2017 \\
A8 & Female & 38 & 21 & Bachelor & 3 & 10.08 .2017 \\
A9 & Male & 35 & 23 & High School & 5 & 10.08 .2017 \\
A10 & Male & 39 & 23 & High School & 6 & 10.08 .2017 \\
A11 & Male & 41 & 27 & Bachelor & 12 & 10.08 .2017 \\
A12 & Female & 33 & 12 & Bachelor & 2 & 10.09 .2017 \\
A13 & Male & 28 & 10 & Bachelor & 2 & 10.09 .2017 \\
\hline
\end{tabular}

The findings concerning the knowledge levels of the bodybuilding athletes participating in the study and their views about the training activities of international and national federations in this topic are presented in Table 2 .

Table 2. The Findings Concerning the Knowledge Levels of the Bodybuilding Athletes Participating in the Study and Their Views about the Education Activities of International and National Federations in This Topic

\begin{tabular}{lcc}
\hline \multicolumn{1}{c}{ Themes } & Frequency (f) & Percentage (\%) \\
\hline Federations Do Not Provide Information Training & 6 & 20.68 \\
Focusing on the Success in the Contest & 3 & 10.34 \\
Low Knowledge Level & 8 & 27.58 \\
Success Without Doping is Difficult & 1 & 3.44 \\
Federations Provide Limited Information & 5 & 17.24 \\
Increase in Doping Use & 2 & 6.89 \\
Doping Use Cannot be Prevented & 1 & 3.44 \\
Statements About Doping Having No Harm & 1 & 3.44 \\
Being Unable to Compete Under Equal Conditions & 2 & 6.89 \\
Total & 29 & 100 \\
\hline
\end{tabular}

When Table 2 is examined, it is observed that the theme that is most frequently mentioned by the bodybuilding athletes participating in the research is "Low Knowledge Level". The statements of the participants in the interviews are as follows.

"I don't think that individuals dealing with bodybuilding sport do not have much information, they are performing this sport ignorantly..." (A3)

"...let you give me the doping substance whatever it is, sir. I can take anything. You just write and give it to me. I can do it. He/she even doesn't know what drug he/she uses. He/she only gives the money..."(A8)

"...In Turkey, our level of knowledge is far lower than those of other countries..." (A10)

"...I think that knowledge levels of bodybuilding athletes concerning the harms of doping are insufficient. This is a reality. I believe that the athletes both at professional level and amateur level do not know the extent of the damages of doping and their effects in short and long terms... and that the knowledge levels of the athletes in this issue is insufficient, and that they are not elucidated enough. I have already observed this." (A11) 
"... Actually, I think that there are athletes, who are not aware of its damages. They obviously experience its side effects and it is apparent, it can be seen with naked eyes. I don't think that anyone considers his/her health... I think at least such an intense and unconscious use of it would not happen." (A12)

The theme that is second most frequently mentioned by the bodybuilding athletes participating in the research is "Federations Do Not Provide Information Training". The statements of the participants in the interviews are as follows.

"Actually, we have never seen these trainings, neither been invited. We have no information. I, for instance, have been a national athlete for many years. I've never been invited, hey guys there is a seminar here, come and have information about doping, nothing. There is no information. Neither from IFBB (International Federation of Bodybuilding), nor from Turkey. Are they conducting among themselves? Probably. What did we do? We organized doping seminars. For whom did you organize?" (A1)

"I definitely think that there is no sufficient training and information... there is not a struggle in real terms. Besides, not only in our branch, we can mention that there is doping use in other branches as well... but for now, I don't see such an attempt." (A2)

"... there is no effort preformed by the federations concerning training about doping or telling it to the people, informing about its harms. They pretend to have such efforts..." (A3)

"... frankly, I've not seen abroad..." (A5)

"...Obviously, I don't think that necessary information is being given to the athletes concerning the harms of doping use. I think that it is roughly hidden by saying the damages of doping... I've never heard an attempt concerning this topic abroad." (A6)

The theme that is third most frequently mentioned by the bodybuilding athletes participating in the research is "Federations Provide Limited Information". The statements of the participants in the interviews are as follows.

"Actually, I have encountered several such kinds of organizations of the federation but I don't think it is too many. Therefore, the use of drugs is approaching to dangerous extents. I mean, it is because the insufficient training. I do not think that there are many individuals, who can give these trainings with a sufficient level of information, either. For this reason, I don't think that there is much training." (A9)

"... Federation, in this issue, yes, is working, organizing doping seminars, but what happens to the heart and veins? Is it possible that, one day, you have high blood pressure or diabetes? Nothing is told about its contents." (A11)

"... There are trivial organizations conducted by our federation in its way, however, it is much more necessary to have information about the harms of doping..." (A13)

The theme that is fourth most frequently mentioned by the bodybuilding athletes participating in the research is "Focusing on the Success in the Contest". The statements of the participants in the interviews are as follows.

"...as per the athletes, they are not interested in the doping side. In their training, they focus on developing the muscle structure and winning the medals..." (A4)

"...despite the fact that they know its harms, the motive behind their use of doping is the country success and being on one's mettle. Therefore, they see no harm in using the doping, paying no attention to their health."(A7)

The theme that is fifth most frequently mentioned by the bodybuilding athletes participating in the research is "Increase in Doping Use". The statements of the participants in the interviews are as follows.

"... in the world, in each year, there is a general increase in the use of doping. The average age of doping use, 25-30, has started to decrease to 18 s..." (A4)

"...what I have observed is that the majority of athletes in other countries in the world are involved in doping..." (A10)

The other theme that is fifth most frequently mentioned by the bodybuilding athletes participating in the research is "Being Unable to Compete Under Equal Conditions". The statements of the participants in the interviews are as follows.

"...It is definitely forbidden to use doping in Turkey; however, the national athlete competes here without using doping. He/She provides the sample, and the result is clean. When he/she travels abroad, all of his/her rivals 
are using doping. The natural athlete cannot be in the first 15 among the athletes, who use doping. I mean, we are not competing under equal conditions..." (A8)

"...when we examine the athletes competing abroad, they definitely take considerable supplements. Unfortunately, the athletes going abroad from Turkey cannot show success on the same podium among them..." (A12)

The theme that is least frequently mentioned by the bodybuilding athletes participating in the research is "Success Without Doping is Difficult". The statements of the participants in the interviews are as follows.

"... It's naturally impossible for the bodybuilding athletes to have such a mass of muscles without using doping substances. This issue has improved in the world to such an extent that, being a Turkey Champion in his/her own country is very difficult for a natural bodybuilding athlete, let alone having a degree at the world championship. No athlete has a chance with the body given to him/her by the God, and without using any foreign substance. I mean, it is impossible." (A3)

The theme that is least frequently mentioned by the bodybuilding athletes participating in the research is "Doping Use Cannot be Prevented". The statements of the participants in the interviews are as follows.

"...The athlete uses doping, but uses it after accepting its harms and benefits. No matter how much explanation you make, or how many articles you publish, if an athlete will compete, and if he/she put his/her mind this, he/she wants to be the champion, and he/she is going to use this. You can never prevent this..." (A5)

The theme that is least frequently mentioned by the bodybuilding athletes participating in the research is "Statements About Doping Having No Harm". The statements of the participants in the interviews are as follows.

"... In this sport branch, doping use can be observed in international platforms. But, as I said, one of the main reasons of the doping use is the existence of people, who disseminate the view that it has no harm. It may motivate to use even more doping." (A6)

\section{Discussion and Conclusion}

The issue that the bodybuilding athletes participating in the research most frequently mentioned is that the bodybuilding athletes have low levels of knowledge concerning doping. The athletes mentioned that they used doping indiscriminately or by learning from others, in other words, they used it unconsciously. This situation is the indicator of the fact that when athletes are not informed accurately and in detail about the harms of the doping, they might tend to use doping. Dinçer (2010) reported that the athletes did not have sufficient information about doping and they might tend to use doping due to this lack of information. Eröz (2007) determined that an important part of national athletes did not have sufficient information about doping. Yildırım (2001) determined that professional and amateur football players did not have sufficient knowledge about doping substances. Gençtürk, Çolakoğlu, and Demirel (2009) reported that wrestlers emphasized that their coaches and administrators did not have sufficient level of information about doping. In a study conducted on triathletes by Gundogdu et al. (2017), it was determined that the triathletes emphasized that their coaches and administrators did not have sufficient level of information about doping. Dallı, Işıkdemir, and Bingöl (2014) concluded that the students at the school of physical education and sports did not have sufficient level of information about the doping. Bayram et al. (2017) determined that the physical education teachers did not have sufficient level of information about the doping.

By contrast with the research findings, Sertbaş et al. (2015) concluded that the athletes had sufficient level of information about the doping. Yildiz et al. (2016) concluded that the athletes doing sports in the teams had higher levels of information about the doping compared to the athletes doing individual sports; additionally, they also concluded that the athletes doing sports for shorter periods had higher levels of information about the doping compared to the ones with longer periods of sport experience.

The second issue that the athletes mentioned is that the federations do not provide information training. This result can be explained by that both the IFBB and the national federations do not attach importance to information training. Actually, there shouldn't be anything more important than the health of the athletes in sports. However, considering the success of the athlete, coach, administrator, and country, the use of doping seems to be the simplest remedy. Whereas, the values at the core of sport teach the athletes competing within the framework of the sport ethics, rather than unfair competition and competing under unequal conditions. Wanjek et al. (2007) indicated to the need concerning development of information about doping among the youth and emphasized the requirement of attitude 
change in the youth against the doping. Yildiz et al. (2016) reported that more than half of the athletes emphasized that doping use was against the sport ethics.

The third issue that the athletes mentioned is that federations provide limited information concerning the doping. The athletes mentioned that they were not being informed in detail about doping by neither international nor national federations. This result can be interpreted that doping trainings have been brushed over by the federations and that they've pretended to be struggling against doping. Gundogdu et al. (2017) reported that the relevant institutions and organizations do not struggle against doping sufficiently.

The fourth issue that the athletes mentioned is that the athletes, who are motivated from the ambition of being a medalist and successful, focus on success in the contest and respond to using doping normally. Barkoukis et al. (2014) concluded that when the athletes believe that they will be successful, they can tend to use doping substances. According to the results of that study, it can be mentioned that the athletes perceive using doping as their rights. Weinberg and Gould (2015) reported that elite athletes do not abstain from cheating for winning. However, it is a known fact that athletes reaching success via doping face health problems after quitting sport. Whereas the most important value that the athletes should gain via sport is the health. Beşiktaş (2016) determined that doping-using bodybuilding athletes encountered high level of exhaustion, and reported that it was due to high level of physical performance that they reached via doping and over self-confidence that they felt while using doping. The exhaustion was emerged as a result of physical, mental, and psychological loss of performance after they quit using doping. Bayram et al. (2017) reported that press, mass media, and means of mass communication supported the use of doping.

The issues that the athletes mentioned with the fifth priority are that there has been a tremendous increase in the doping use and therefore, competence under equal conditions is no more possible. This result is an indicator of that the doping use has reached to a great extent particularly for the elite level bodybuilding athletes. Besides, it can also be interpreted that doping substances have been a part of contests. Moreover, it is known that a zero tolerance approach having been displayed in Turkey in recent years. It can be mentioned that this situation creates an atmosphere, where it is perceived that athletes from other nationalities, who use doping, and Turkish ones are competing under unequal conditions. In fact, if all of the countries struggle against doping and if it is ensured that all of the athletes will participate in contests without doping, the values to be gained by means of sport will rise to prominence. Yildiz et al. (2016) determined that athletes emphasized that the state did not have a policy for preventing the use of doping for the athletes. Eröz (2007) reported that the state did not do its part in terms of preventing doping in sport, awareness-rising, informing about harms of the doping, unfair competition, and that doping contradicts sport ethics. Alaranta et al. (2006) stated that it was not sufficient to control the doping by means of tests, and it was necessary for the athletes to make substantial changes concerning their attitudes. Bloodworth and McNamee (2010) determined that the athletes, in general, perceived that the use of doping substances at their own branches was a common problem in many countries.

The least stated issues by the athletes are that success without doping is not possible, the use of doping cannot be prevented, and the use of doping will not harm the athletes. These results can be explained by that the idea is common that success is impossible without doping particularly in bodybuilding sport, and thus, it is not possible to restrain the athletes from using doping. Moreover, the athletes were indoctrinated by their coaches, athlete friends, and administrators that doping use is not harmful. Morente-Sánchez and Zabala (2013) determined that motives behind the doping use are increase in performance, financial gain, acceleration in the recovery, and preventing malnutrition. Laure, Thouvenin, and Lecerf (2001) mentioned that professional trainers did not have the necessary attitude and training for restraining the athletes from using doping.

As the conclusion, it was revealed by the results of the research that the elite level bodybuilding athletes used the doping substances unconsciously. In order to prevent this, only organizing seminars, in which the harms of doping are told, will not be sufficient. In addition to the doping training, sport values training seminars should be frequently repeated including the themes such as equality, righteousness, honesty, respect, sensitivity, being fair, obeying the rules etc. Thus, it is evaluated that a stronger struggle will be possible by means of these training organizations that will influence the conscious of the athletes. For further studies, it is suggested that interviews should be conducted with foreign bodybuilding athletes from other countries. 


\section{References}

Alaranta, A., Alaranta, H., Holmila, J., Palmu, P, Pietila, K., \& Helenius, I. (2006). Self-reported attitudes of elite athletes towards doping: differences between type of sport. International Journal of Sports Medicine, 27(10), 842-846. https://doi.org/10.1055/s-2005-872969

Barkoukis, V., Lazuras, L., \& Tsorbatzoudis, H. (2014). Beliefs about the causes of success in sports and susceptibility for doping use in adolescent athletes. Journal of Sports Sciences, 32(3), 212-219. https://doi.org/10.1080/02640414.2013.819521

Bayram, M., Bayraktar, G., Tozoğlu, E., \& Doğar, A. (2017). Determining doping knowledge levels of physical education and sports teachers. International Journal of Education, Science and Technology, 3(1), 23-31.

Beşiktaş, M. Y. (2016). Measurement of male bodybuilding athletes, who use doping, their burnout situation after competation. Istanbul University Journal of Sport Science, 6(3), 29-37.

Bloodworth, A., \& McNamee, M. (2010). Clean Olympians? Doping and anti-doping: The views of talented young British athletes. International Journal of Drug Policy, 21, 276-282. https://doi.org/10.1016/j.drugpo.2009.11.009

Dallı, M., Işıkdemir, E., \& Bingöl, E. (2014). Determination of doping knowledge level of physical education and sports college students. International Journal of Science Culture and Sport, Special Issue(2), 11-20. https://doi.org/10.14486/IJSCS174

Dinçer, N. (2010). The determining of knowledge level related to doping in elite athletes. Selcuk University Institute of Health Sciences. Master Thesis, Konya, Turkey.

Eröz, M. F. (2007). Determination of information levels of doping and ergogenic help in the sportsmen of national level, athletics, wrestling, judo and weightlifting. Dumlupınar University Social Sciences Institute, Master Thesis, Kütahya, Turkey.

Gençtürk, G., Çolakoğlu, T., \& Demirel, M. (2009). A research for determine the intelligence level of national sportsman for doping (wrestling sample). Nigde University Journal of Physical Education and Sport Sciences, $3(3), 213-221$.

Gundogdu, C., Celebi, E., Beyazcicek, O., Beyazcicek, E., Tufekci, S., \& Özmerdivenli, R. (2017). The determination of opinions of triathlon athletes on doping and anti-doping matters. Konuralp Medical Journal, $9(1), 63-69$.

Güner, R. (2016). Doping and fight against doping. Turkiye Klinikleri Journal of Sports Sciences, 2(3), 49-65.

Işıkoğlu, N. (2005). Eğitimde nitel araştırma. Eğitim Araştırmaları, 20, 158-165.

Kuş, E. (2007). Nicel-nitel araştırma teknikleri. Ankara: Anı Publisher.

Laure, P., Thouvenin F., \& Lecerf, T. (2001). Attitudes of coaches toward doping. The Journal of Sports Medicine and Physical Fitness, 41(1), 132-136.

Melzer, M., Elbe, A. M., \& Brand, R. (2010). Moral and ethical decision-making: A chance for doping prevention in sports? Nordic Journal of Applied Ethics, 4(1), 69-85. https://doi.org/10.5324/eip.v4i1.1741

Morente-Sanchez, J., \& Zabala, M. (2013). Doping in sport: A review of elite athletes' attitudes, beliefs, and knowledge. Sports Medicine, 43(6), 395-411. https://doi.org/10.1007/s40279-013-0037-x

Punch, K. F. (2005). Sosyal araştırmalara giriş (D. Bayrak, H. B. Arslan, Z. Akyüz, Trans.). Ankara: Siyasal Publisher.

Sertbaş, K., Akdeniz, H., Yılmaz, A., Çalik, F., \& Şentürk, U. (2015). Evaluation of ergogenic matter and doping usage knowledge of Turkish national athletes. Medicina Sportiva, 11(3), 2591-2600.

Tavşancil, E., \& Aslan, E. (2001). İçerik analizi ve uygulama örnekleri. İstanbul: Epsilon Publisher.

Taware, G. B., \& Bansode, D. G. (2016). Doping in sports. National Journal of Basic Medical Sciences, 6(2), 89-92.

Unal, M., \& Ozer Unal, D. (2004). Gene doping in sports. Sports Medicine, 34(6), 357-362. https://doi.org/10.2165/00007256-200434060-00002

Vatanoğlu, E., \& Hot, İ. (2011). Doping in the triangle of health-ethics-law: Is there any clean sport? Turkiye Klinikleri Journal of Medical Ethics-Law and History, 19(3), 175-181. 
Yıldırım, E. (2001). The education level of sportsmen and their knowledge level about doping and analysis of trend

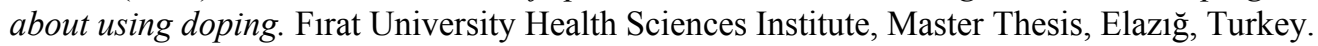

Yıldız, M., Pala, A., Biner, M., \& Göral, Ş. (2016). Examining of individual and team sports athletes' opinion about doping. International Refereed Journal of Orthopaedic Traumatology and Sports Medicine, 6, 1-12. https://doi.org/10.17372/OTSHD.2016616641

Wanjek, B., Rosendahl, J., Strauss, B., \& Gabriel, H. H. (2007). Doping, drugs and drug abuse among adolescents in the state of Thuringia (Germany): Prevalence, knowledge and attitudes. International Journal of Sports Medicine, 28(4), 346-353. https://doi.org/10.1055/s-2006-924353

Weinberg, R. S., \& Gould, D. (2015). Spor ve egzersiz psikolojisinin temelleri. In M. Şahin, Z. Koruç (Trans. Ed.,), Yarışma ve iş birliği. (S. A. Özdurmuş, Trans.). Ankara: Nobel Akademik Publisher.

Yıldırım, A., \& Şimşek, H. (2006). Sosyal bilimlerde nitel araştırma yöntemleri. Ankara: Seçkin Publisher.

http://www.karate.gov.tr/source/2014/dopingle_mucadele/Doping_sporda_ilac_suistimali.pdf 